\title{
A STUDY OF NITROGEN METABOLISM IN THE DAIRY COW.
}

\author{
By CHARLES CROWTHer, M.A., Ph.D. \\ aND HERBERT ERNEST WOODMAN, D.Sc., Ph.D.
}

The work outlined in the present communication was carried out during the years 1916-19 in the Institute for Research in Animal Nutrition of the University of Leeds.

IN an earlier communication ${ }^{1}$ dealing with the results of a series of digestibility determinations carried out by us with two sheep, attention was directed to the fact that, when the averages for consumption and excretion of nitrogen in the different periods were arranged in the order of increasing nitrogen consumption, the retention of nitrogen in the body of the sheep rose only up to a certain point and then fell. The essential data are reproduced below:

\begin{tabular}{|c|c|c|c|c|c|}
\hline \multirow[b]{3}{*}{ Period } & \multirow{3}{*}{ Nature of ration } & \multicolumn{4}{|c|}{ Average per day } \\
\hline & & \multicolumn{2}{|c|}{ Nitrogen digested } & \multicolumn{2}{|c|}{$\begin{array}{c}\text { Nitrogen retained } \\
(+) \text { or lost }(-) \\
\text { by sheep }\end{array}$} \\
\hline & & Sheep 1 & Sheep 2 & Sheep l & Sheep 2 \\
\hline $\begin{array}{c}\text { I } \\
\text { IV } \\
\text { V } \\
\text { III } \\
\text { VI }\end{array}$ & $\begin{array}{l}\text { Hay + palm kernel cake I } \\
\text { Hay alone } \ldots \\
\text { Hay + palm kernel cakes I and } \dddot{\text { II }} \\
\text { Hay + extracted palm k. meal ... } \\
\text { Hay + undec. cotton cake } \\
\text { Hay + dried yeast } \quad \ldots\end{array}$ & $\begin{array}{r}\text { gm. } \\
6 \cdot 88 \\
9 \cdot 09 \\
11 \cdot 40 \\
12 \cdot 22 \\
12 \cdot 31 \\
18 \cdot 10\end{array}$ & $\begin{aligned} \text { gm. } \\
7 \cdot 38 \\
9 \cdot 61 \\
12 \cdot 48 \\
13 \cdot 12 \\
12 \cdot 96 \\
18 \cdot 28\end{aligned}$ & $\begin{array}{l}\text { gm. } \\
-0 \cdot 37 \\
+1 \cdot 93 \\
+3 \cdot 80 \\
+3 \cdot 33 \\
+3 \cdot 25 \\
+2 \cdot 94\end{array}$ & $\begin{array}{l}\mathrm{gm} . \\
1 \cdot 94 \\
2 \cdot 14 \\
4 \cdot 76 \\
2 \cdot 15 \\
3 \cdot 76 \\
1 \cdot 35\end{array}$ \\
\hline
\end{tabular}

It will be noted that each sheep showed the maximum retention of nitrogen in Period II, in which about $12 \mathrm{gm}$. digestible nitrogen, or roughly $17 \mathrm{gm}$. total nitrogen (= $106 \mathrm{gm}$. total crude protein) per head per day $(=2.4 \mathrm{~kg}$. total crude protein per $1000 \mathrm{~kg}$. live-weight) were consumed. In the periods following this in the table, as the nitrogenconsumption increases the nitrogen-retention falls steadily.

These results suggest that, judged by nitrogen-retention, there is an optimum point of protein supply, above or below which nitrogen-retention is reduced. It was realised, however, that this series of observations could not be regarded as in any way conclusive on this point, in view of

1 Journ. of Agric. Sci. 8 (1917), 447. 
the varying sources of protein-supply in the different periods, and the fact that the order in which the diverse rations were fed was not that of increasing nitrogen-content. It would be equally legitimate, for example, to account for the reduced nitrogen-retention in Periods III and VI, by assuming the proteins of cottonseed cake and yeast respectively to be of lower metabolic efficiency than those of palm kernel cake.

Both alternatives engaged our interest, as we were at the time contemplating a comprehensive study of the nutritional requirements of the dairy cow, in which, as is well-known, protein-supply plays a part of outstanding importance. It has been established that up to a certain point increased protein consumption leads to increased secretion of milk. Does this point coincide with that of maximum retention of nitrogen in the body? Does the amount of food-protein required to produce the latter vary with the qualitative character of the ration? Is the maximum of nitrogen-retention constant for any one individual or variable according to the feeding? Before attempting to secure answers to these questions we decided first to test whether, by feeding cows on rations of the same qualitative composition, but of successively increasing protein-content, and determining the nitrogen-retention, we could detect an optimum of protein-supply, such as had been suggested by the records of the sheep experiments. Further, in order to avoid the complications that pregnancy and lactation would introduce, we selected as test animals two fully grown Shorthorn cows, not in calf, and not prodúcing milk.

\section{FIRST EXPERIMENT.}

(196 days, November, 1916-June, 1917.)

For reasons stated later this experiment cannot be regarded as entirely satisfactory and consequently need only be dealt with in outline.

The two cows were first brought approximately into nitrogenous equilibrium on a daily ration of $14 \mathrm{lb}$. "seeds" hay, supplying about $122 \mathrm{gm}$. nitrogen. After determining over a given period the daily balance between the amounts of nitrogen consumed and excreted, the ration was increased by adding $2 \mathrm{lb}$. maize meal per day (containing about $13 \mathrm{gm}$. nitrogen) and the effect on the nitrogen balance was then investigated. This was followed by several further experimental periods, in each of which the ration was increased by $2 \mathrm{lb}$. maize meal.

The general arrangements for the experiment and the methods of analysis, etc., followed were similar to those described in detail later in this paper. 


\section{A Study of Nitrogen Metabolism in the Dairy Cow}

In all changes of feeding a transitional period of at least nine days was allowed, whilst the experimental period consisted of at least twelve days, giving a minimum period of three weeks between each change. The essential data obtained are summarised in Table I.

Table I.

Cow A. (Initial weight, $1033 \mathrm{lb}$.)

\begin{tabular}{|c|c|c|c|c|c|}
\hline \multirow[b]{2}{*}{ Period } & \multirow[b]{2}{*}{ Duration } & \multicolumn{2}{|c|}{ Daily ration } & \multirow{2}{*}{$\begin{array}{c}\text { Total } N \text { consumed } \\
\text { per day }\end{array}$} & \multirow{2}{*}{$\begin{array}{c}\text { Gain }(+) \text { or } \\
\text { Loss }(-) \text { of } \\
\text { N by cow } \\
\text { per day }\end{array}$} \\
\hline & & Hay & Maize & & \\
\hline & days & lb. & lb. & $\mathrm{gm}$. & gm. \\
\hline I & 24 & 14 & 0 & 121.9 & -8.2 . \\
\hline II & 32 & 14 & 2 & $134 \cdot 1$ & $\begin{array}{r}7.6 \\
+\end{array}$ \\
\hline III & 21 & 14 & 4 & 151.8 & +18.1 \\
\hline IV & 21 & 14 & 6 & $168 \cdot 4$ & $\begin{array}{r}+20.6 \\
\end{array}$ \\
\hline $\mathrm{V}$ & 28 & 14 & 8 & 161.9 & $+10 \cdot 4$ \\
\hline VI & 21 & $16 \cdot 5$ & 8 & $172 \cdot 4$ & $+1 \cdot 1$ \\
\hline VII & 28 & 16.5 & 10 & 185.7 & +6.0 \\
\hline vIII & 21 & $16 \cdot 5$ & 12 & $201 \cdot 9$ & +17.8 \\
\hline$[\mathrm{X}$ & 31 & 16.5 & $10^{*}$ & $194 \cdot 3$ & $\begin{array}{r}15.7 \\
\end{array}$ \\
\hline
\end{tabular}

Cow B. (Initial weight, $959 \mathrm{lb}$.)

$\begin{array}{rrrrrr}\text { I } & 32 & 14 & 0 & 124 \cdot 3 & +5 \cdot 0 \\ \text { II } & 32 & 14 & 2 & 133 \cdot 3 & +8 \cdot 4 \\ \text { III } & 21 & 14 & 4 & 148 \cdot 9 & +18 \cdot 9 \\ \text { IV } & 21 & 14 & 6 & 164 \cdot 3 & +20 \cdot 4 \\ \text { V } & 28 & 14 & 8 & 161 \cdot 4 & +18 \cdot 1 \\ \text { VI } & \overline{V I I} & \overline{14} & \overline{10} & 170 \cdot 3 & +21 \cdot 0 \\ \text { VIII } & - & - & - & - & -\end{array}$

* The concentrated food during this period consisted of $9 \mathrm{lb}$. maize $+1 \mathrm{lb}$. linseed cake.

The investigation proceeded quite smoothly up to Period $V$, when it became necessary to draw a fresh consignment of hay. This proved unfortunately to be decidedly poorer in nitrogen than the previous consignment, and consequently, despite the added $2 \mathrm{lb}$. of maize, the nitrogen consumption for Period V worked out rather less than for Period IV. In order to overcome this difficulty the basal ration of hay was increased for Period VI to $16.5 \mathrm{lb}$. per day, the maize meal being retained as in Period V at $8 \mathrm{lb}$. Unfortunately, although Cow A consumed the increased ration of hay satisfactorily, Cow B could not be induced to do so, and in consequence this cow had to be kept for the remainder of the experiment on the lower ration ( $14 \mathrm{lb}$.) of hay, so that from this point the records of the two cows were not strictly comparable.

Further difficulty was experienced towards the end of the experiment in inducing the cows to consume the rations completely and it was obvious that we were approaching the limits of their appetites. This was the 
more marked with Cow $B$, and for this reason we were obliged to reject the records of this cow for Periods VI and VIII.

If the data for nitrogen-retention be examined, it will be seen that with each cow up to Period IV there were distinct indications that the daily retention of nitrogen was approaching a maximum value and, but for the regrettable difficulty with the hay, it seems probable that this limit would have been reached in Period V, since in the later periods, despite increased intake of nitrogen, no higher retention than that of Period IV was recorded. A slight increase is indicated with Cow B in Period VII but it will be noted that the nitrogen intake in this case was practically the same as for Cow A in Period IV, so that the maximum retention of nitrogen under the conditions of experiment would seem to be associated with a nitrogen intake of roughly $170 \mathrm{gm}$. per day $(=1060$ gm. crude protein). Taking the average weight of the cows for Period V this represents a daily intake of crude protein of $2.34 \mathrm{~kg}$. per $1000 \mathrm{~kg}$. live-weight, or almost exactly the same figure as was deduced for the sheep from the data obtained in the digestibility trials. This confirmation is particularly interesting in that the diets in the different periods of the sheep tests varied considerably in qualitative character, and the conclusion suggests itself that, when fed along with hay, the proteins of maize, cottonseed, palm kernels and yeast are of equal value so far as capacity to effect protein storage in the body is concerned.

It would appear therefore from these experiments that for the lastnamed purpose the optimum protein-supply in the food is in the neighbourhood of $2.4 \mathrm{~kg}$. crude protein, or say $1.7 \mathrm{~kg}$. digestible crude protein per $1000 \mathrm{~kg}$. live-weight. This, of course, applies only to animals such as those under test which were not subject to any losses of nitrogen other than those voided in faeces and urine, and were free from any exceptional internal needs for protein such as arise during pregnancy.

It will be noted from Table I that the duration of the different periods varied from 21 to 32 days. It was anticipated that a period of 21 days would afford ample time for the re-establishment of nitrogen equilibrium after the disturbance due to change of ration. It soon became evident, however, that this was not the case, and the records of Periods IV to VI bring this out clearly. For reasons already given the nitrogen-consumption remained relatively constant throughout these three periods, which may therefore be grouped together as one long period. Viewed in this light it is seen that the establishment of nitrogen equilibrium is a much slower process than we had assumed, the nitrogen-retention persisting, though at a steadily diminishing rate, throughout the whole interval of 


\section{A Study of Nitrogen Metabolism in the Dairy Cow}

70 days. In this particular, therefore, our scheme of experiment would appear to have been defective in that the change of ration from period to period was evidently made before the influence of the earlier ration on nitrogen-retention had been exhausted. Accordingly, before proceeding further with the comprehensive programme of experimental work on these lines which lay before us, we thought it desirable to make a more prolonged study of nitrogen-retention under conditions of roughly constant nitrogen-consumption, and a further experiment was undertaken in November, 1917, and developed later into a study of nitrogen-retention during pregnancy and lactation, the whole experiment covering a period of two years.

\section{SECOND EXPERLMENT.}

(November, 1917-November, 1919.)

General Plan of Experiment.

Two Shorthorn cows, C and D, similar to those used for the first experiment, both "dry" and not in calf, were weighed and placed on a daily ration consisting of $20 \mathrm{lb}$. "seeds" hay. The nitrogen-balance in both cows was followed continuously, except for the one week monthly during which the cows were weighed and an interval of 10 weeks at the end of the first year. After a period of 302 days (including 255 days for which the nitrogen-balance records were obtained) during which both cows received identical treatment, Cow $\mathrm{D}$ was put to the bull, whilst Cow $\mathrm{C}$ remained unserved as control. The nitrogenbalance measurements were continued for both cows throughout the period of pregnancy of Cow $D$ and subsequent parturition, and were further extended well into the period of lactation. For Cow D the experiment extended over periods of 302 days "dry" and not in calf, 284 days "dry" but in calf, and 136 days in milk, a total of 722 days throughout the whole of which period Cow $\mathrm{C}$ was maintained dry and not in calf. Samples for nitrogen-balance determinations were taken on 546 days during this period.

Both this and the foregoing experiment were carried out in a building specially designed for work of this character. The floor was of cement, graded and grooved to secure rapid drainage, each cow-stall being provided with a separate drain, so arranged that the drainage could be easily collected for purposes of weighing and sampling. Preliminary tests showed that any liquid falling on the floors of the stalls could be recovered within 2 or 3 per cent., whilst by spraying the floors occasionally with 
water a still higher degree of completeness could be obtained in the recovery of urinary nitrogen.

\section{Experimental details.}

Collection, Sampling and Analysis of Faeces. The faeces were collected into weighed covered buckets. The 24-hours' collection was weighed, thoroughly mixed, and by quartering, reduced to a small sample. Onetenth of the daily faeces was preserved in a closed vessel with the addition of a little toluene. In this manner, composites were made up twice weekly, representing the collection over three and four days respectively. Preliminary tests had shown that the loss of nitrogen was inappreciable when the faeces were stored in this manner over a period of several days. The composite samples were well mixed and small samples were drawn from the bulk for analysis. The nitrogen-content was determined in triplicate by means of the Kjeldahl method.

Collection, Sampling and Analysis of Urine. The urine was collected in weighed buckets, the drainage being assisted by frequent spraying of the floors with water. No litter was used in the stalls. The daily output of urine was weighed and, after thorough stirring, one-tenth of the total weight was ladled out, acidified with 20 c.c. $\mathrm{H}_{2} \mathrm{SO}_{4}(1: 1)$ and preserved in a Winchester bottle. Composites were made up in this way twice weekly and the nitrogen-content of the samples was determined by the $\mathrm{Kjeldahl}$ method. Under the conditions of collection the faeces were always contaminated with urine, and the urine was diluted to some extent by the water used in spraying. This was immaterial, however, as it was only required to measure the total voided nitrogen.

Length of periods and weighing of cows. The periods were mainly of about 18 days' duration. At the end of each period the cows were weighed on three successive days under comparable conditions.

Feeding of cows and analysis of foodstuffs. The hay was fed in four equal allowances during the day, care being taken that the cows had consumed the hay completely before being left for the night. Water was given ad lib. Composite samples of the feeds were made up by reserving weighed representative samples daily. Two independent hay composite samples were made up in each period, and the dry matter and nitrogen-contents of these were determined, the mean results for the two samples being used in the calculation of the nitrogen-balances. From time to time representative samples were made up from the period composites and complete analyses were carried out. Moisture deter- 


\section{A Study of Nitrogen Metabolism in the Dairy Cow}

minations were made daily on independent hay samples, since this factor was found to be subject to considerable variation.

Analysis of milk. Cow D was milked twice daily during its period of lactation and half-weekly composites were made up. The samples were preserved by the addition of one or two drops of formalin. The determination of the nitrogen in the milk samples was carried out in duplicate by the Kjeldahl method.

The experiments were carried out at the Manor Farm, Garforth, (Experimental Farm of the University of Leeds and the Yorkshire Council for Agricultural Education). The care of the animals was in the experienced hands of Mr H. J. Hargraves, N.D.A., to whom we are greatly indebted for the skill and accuracy with which this important side of the work was carried out.

Table II. Analysis of seeds hay and linseed cake composite. (Calculated on dry matter.)

\begin{tabular}{|c|c|c|c|c|c|c|c|}
\hline \multirow{2}{*}{$\begin{array}{c}\text { Days represented } \\
\text { by sample ... }\end{array}$} & \multicolumn{6}{|c|}{ Seeds hay } & \multirow{2}{*}{$\begin{array}{l}\text { Linseed } \\
\text { cake }\end{array}$} \\
\hline & $1-68$ & $69-194$ & $195-295$ & $296-499$ & $500-660$ & $661-722$ & \\
\hline $\begin{array}{l}\text { Crude protein ... } \\
\text { True protein ... } \\
\text { Ether extract ... } \\
\text { Nitrogen-free }\end{array}$ & $\begin{array}{l}12 \cdot 46 \% \\
10 \cdot 25 \\
1.52\end{array}$ & $\begin{array}{l}12.41 \% \\
11.03 \\
1.95\end{array}$ & $\begin{array}{c}11.08 \% \\
9.75 \\
1.79\end{array}$ & $\begin{array}{l}12 \cdot 86 \% \\
11 \cdot 45 \\
1 \cdot 65\end{array}$ & $\begin{array}{l}1027 \% \\
8 \cdot 73 \\
1 \cdot 65\end{array}$ & $\begin{array}{l}10 \cdot 29 \% \\
9 \cdot 17 \\
1.55\end{array}$ & $\begin{array}{l}33 \cdot 18 \% \\
23 \cdot 86 \\
10 \cdot 15\end{array}$ \\
\hline $\begin{array}{cc}\text { extractives } & \ldots \\
\text { Crude fibre } & \ldots \\
\text { Ash } & \ldots\end{array}$ & $\begin{array}{r}50 \cdot 23 \\
28 \cdot 90 \\
6 \cdot 89\end{array}$ & $\begin{array}{r}45 \cdot 68 \\
33 \cdot 42 \\
6 \cdot 54\end{array}$ & $\begin{array}{r}51 \cdot 50 \\
29 \cdot 64 \\
5 \cdot 99\end{array}$ & $\begin{array}{r}48.50 \\
30.94 \\
6.05\end{array}$ & $\begin{array}{r}49 \cdot 23 \\
31 \cdot 82 \\
7 \cdot 03\end{array}$ & $\begin{array}{r}49.92 \\
31 \cdot 22 \\
7 \cdot 02\end{array}$ & $\begin{array}{r}38.95 \\
10.71 \\
7.01\end{array}$ \\
\hline
\end{tabular}

It will be noted that the composition of the hay, and in particular, its content of protein, were subject to considerable variation during the course of the trial. This rendered necessary, in the later stages of the experiment, a slight increase in the amount of hay fed per day, in order to maintain the amount of protein consumed per day at its initial level. Another factor disturbing to some extent and difficult to regulate was the great variation to which the moisture-content of the hay was subject from day to day. For these reasons it was impossible to avoid an appreciable variation in the nitrogen-supply without recourse to methods which the resources at our disposal did not permit. It will be seen from the second column of Table III what the extent of this variation was.

Comments on Table III (First Main Period of Experiment).

We cannot attempt to tabulate here in detail the whole of the data accumulated day by day during the trial. The figures given in Table III 'therefore represent daily averages for the different periods, the nitrogenbalance columns giving the average daily gain or loss of nitrogen by the 
cows for each respective period. The weight columns give the gain or loss of weight of the cows over the whole period.

\section{Table III.}

Summary of nitrogen-balances for Cow C and Cow $D$ up to day 295.

Daily ration : $20 \mathrm{lb}$. seeds hay (average dry matter per day $=7600 \mathrm{gm}$.).

\begin{tabular}{|c|c|c|c|c|c|c|c|}
\hline \multirow[b]{2}{*}{$\begin{array}{l}\text { Period } \\
\text { in days }\end{array}$} & \multicolumn{4}{|c|}{ Cow $\mathrm{C}$} & \multicolumn{3}{|c|}{ Cow D } \\
\hline & $\begin{array}{l}\text { N con- } \\
\text { sumed } \\
\text { (average } \\
\text { per day) }\end{array}$ & $\begin{array}{l}\text { Total N } \\
\text { volded } \\
\text { (average } \\
\text { per day) }\end{array}$ & $\begin{array}{l}\text { Mean } \\
\text { nitrogen- } \\
\text { balance } \\
\text { per day }\end{array}$ & $\begin{array}{c}\text { Change in } \\
\text { weight }\end{array}$ & $\begin{array}{c}\text { Total N } \\
\text { vorded } \\
\text { (average } \\
\text { per day) }\end{array}$ & $\begin{array}{l}\text { Mean } \\
\text { nitrogen- } \\
\text { balance } \\
\text { per day }\end{array}$ & $\begin{array}{l}\text { Change } \\
\text { in } \\
\text { weight }\end{array}$ \\
\hline $\begin{array}{r}1-19 \\
23-47 \\
52-68 \\
72-89 \\
93-110 \\
114-131 \\
335-152 \\
156-173 \\
177-194 \\
198-215 \\
219-236 \\
240-257 \\
261-276 \\
282-295\end{array}$ & $\begin{array}{c}\text { gm. } \\
136.0 \\
151.1 \\
144.5 \\
152.9 \\
151.8 . \\
1486 \\
152.3 \\
148.9 \\
147.3 \\
165.3 \\
141.8 \\
136.6 \\
146.5 \\
138.7\end{array}$ & $\begin{array}{l}\text { gm. } \\
130 \cdot 1^{*} \\
143 \cdot 7 \\
139 \cdot 2 \\
150 \cdot 3 \\
150 \cdot 2 \\
151 \cdot 2 \\
149.1 \\
150 \cdot 9 \\
147 \cdot 8 \\
155 \cdot 6 \\
143 \cdot 0 \\
135 \cdot 0 \\
135 \cdot 9 \\
134 \cdot 1\end{array}$ & $\begin{array}{l}\text { gm. } \\
+59 \\
+7.4 \\
+53 \\
+2.6 \\
+16 \\
+2.6 \\
+3.2 \\
-2.0 \\
-0.5 \\
+9.7 \\
+1.2 \\
+1.6 \\
+10.6 \\
+4.6\end{array}$ & $\begin{array}{l}\text { lb. } \\
-13 \frac{2}{3} \\
-5 \frac{2}{3} \\
+11 \frac{2}{8} \\
-3 \frac{1}{8} \\
+2 \\
+30 \frac{1}{5} \\
+2 \\
+16 \frac{1}{3} \\
-3 \frac{2}{3} \\
+15 \frac{1}{3} \\
+22 \frac{2}{3} \\
+\quad 7 \\
+15 \frac{2}{3} \\
+1 \frac{1}{5}\end{array}$ & $\begin{array}{l}\text { gm. } \\
132.4^{*} \\
139.7 \\
136.2 \\
147.7 \\
148.2 \\
148.9 \\
146.8 \\
145.4 \\
142.5 \\
151.8 \\
141.0 \\
130.2 \\
135.7 \\
131.0\end{array}$ & $\begin{array}{l}\text { gm. } \\
+36 \\
+11 \cdot 4 \\
+\quad 8 \cdot 3 \\
+\quad 5 \cdot 2 \\
+3 \cdot 6 \\
+0 \cdot 3 \\
+5 \cdot 5 \\
+\quad 3 \cdot 5 \\
+4 \cdot 8 \\
+13 \cdot 5 \\
+0.8 \\
+6 \cdot 4 \\
+10 \cdot 8 \\
+7 \cdot 7\end{array}$ & $\begin{array}{l}\mathrm{lb} \\
-43 \\
+15 \\
+11 \frac{1}{3} \\
-11 \\
+12 \frac{1}{5} \\
+\quad 6 \frac{9}{5} \\
+15 \\
+25 \frac{2}{5} \\
-14 \frac{2}{4} \\
+19 \\
+33 \frac{1}{3} \\
+10 \\
+4 \\
+24 \frac{2}{8}\end{array}$ \\
\hline
\end{tabular}

Condensed summary.

\begin{tabular}{|c|c|c|c|c|c|}
\hline \multirow{2}{*}{$\begin{array}{c}\text { Analytical } \\
\text { days }\end{array}$} & \multirow{2}{*}{$\begin{array}{c}\text { Total N } \\
\text { consumed }\end{array}$} & \multicolumn{2}{|c|}{ Total N retained } & \multicolumn{2}{|c|}{ Nett change of weight } \\
\hline & & 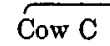 & Cow D & Cow $\mathrm{C}$ & Cow D \\
\hline 255 & $37,616 \mathrm{gm}$. & $866 \mathrm{gm}$. & $1571 \mathrm{gm}$. & $+109 \mathrm{lb}$ & $+118 \frac{1}{3} 1 k$ \\
\hline
\end{tabular}

* Includes small amount of nitrogen from milk (cows not quite dry at beginning of trial).

Initial weights of cows $\begin{cases}\text { Cow C. } & 1229 \mathrm{lb} . \\ \text { Cow.D. } & 1266 \mathrm{lb} .\end{cases}$

According to current views on protein metabolism we might expect to find, on introducing a given ration supplying protein in excess of the requirements of the basal metabolism, that nitrogen storage took place at the outset, but that the rate of storage steadily fell until nitrogenequilibrium was re-established. This process is clearly evident in the records of our two cows. Taking Cow $\mathrm{C}$ for example, and overlooking the first 20 days as preliminary, it will be seen that the nitrogen-retention steadily fell and nitrogenous equilibrium was ultimately roughly established, though not until the lapse of about 90 days. Subsequently, between days 93 and 194 the cow was in almost perfect nitrogen-equilibrium, but this was then disturbed by a rise in nitrogen-consumption due to an abrupt rise in the protein-content of the hay. The effect of 


\section{A Study of Nitrogen Metabolism in the Dairy Cow}

this seems to have passed away quickly and between days 219 and 257 nitrogen-equilibrium again prevailed. Thus, but for the abnormal period of days 198-215, equilibrium was maintained over a period of 164 days. It was all the more surprising therefore in the subsequent periods from day 261 to day 295 to find that nitrogen storage was again taking place, a phenomenon of which the explanation is not very obvious. It certainly cannot be attributed to more than a small extent to the comparatively small rise in nitrogen-consumption in the period of days 261-278.

The record of Cow D is very similar for the first part of the period, the nitrogen-retention falling steadily until the 100th day or thereabouts when nitrogen-equilibrium was established. The period from the 114th to the 131st day shows an almost perfect nitrogen-balance, but subsequently a curiously persistent small retention of nitrogen was recorded throughout the remaining 164 days, increasing appreciably, as in the case of Cow C, in the last stages of the period.

Over the whole period, out of $37.6 \mathrm{~kg}$. nitrogen consumed by each cow, Cow C retained $866 \mathrm{gm}$. and Cow D $1571 \mathrm{gm}$., whilst the gains in live-weight were $109 \mathrm{lb}$. and $118 \mathrm{lb}$. respectively.

No clear correlation is evident between the nitrogen-balances and the weight changes. For instance, between days 114 and 131, Cow $\mathrm{C}$ showed a daily negative nitrogen-balance of $2.6 \mathrm{gm}$. and an increase in weight of $30 \frac{1}{3} \mathrm{lb}$. for the period. Between days 72 and 89 , however, where the cow gained $2.6 \mathrm{gm}$. of nitrogen daily, the weight of the cow suffered a loss of $3 \frac{1}{3} \mathrm{lb}$. for the period.

The extremely irregular variation of the figures in the nitrogenbalance and weight columns, and the disconcerting rise in the nitrogenretention after 240 days of relatively uniform feeding, show clearly the danger of placing too much reliance on conclusions drawn from the results of short-period experiments with cattle. A three-weeks' period in work of this character is obviously far too short.

Comments on Table IV (Second Main Period of Experiment).

Cow D was put to the bull on September 6, 1918 (day 303), and the measurements of the nitrogen-balances were suspended until November 8, 1918 (day 366). This break in the measurements was unfortunate, since, on resumption of the trials, distinct indications were obtained that the protein metabolism of Cow $\mathrm{D}$ had undergone a marked disturbance in the early stages of pregnancy. Up to day 295 , Cow D had shown throughout a uniformly higher positive nitrogen-balance than Cow C. On resumption, however, Cow D was found to be distinctly in 
nitrogen deficit, whereas Cow $\mathrm{C}$ still retained a positive nitrogen-balance. If the nitrogen-balances throughout were plotted graphically against the days of duration of the trial, it would be found that the curves for the

\section{Table IV.}

Summary of nitrogen-balances during period of pregnancy of Cow $D$.

Daily ration:

(Days 366-575.)

Cow $C$ (to day 558): $20 \mathrm{lb}$. seeds hay* (average dry matter per day $=7340 \mathrm{gm}$.).

Con $D$ (to day 407): $20 \mathrm{lb}$. seeds hay (average dry matter per day $=7250 \mathrm{gm}$.).

(Day 408-562): $21 \mathrm{lb}$. seeds hay (average dry matter per day $=7740 \mathrm{gm}$.).

\begin{tabular}{|c|c|c|c|c|c|c|c|c|}
\hline \multirow[b]{2}{*}{$\begin{array}{c}\text { Period } \\
\text { in } \\
\text { days }\end{array}$} & \multicolumn{4}{|c|}{ Cow $\mathrm{C}$} & \multicolumn{4}{|c|}{ Cow D } \\
\hline & $\begin{array}{l}\text { N con- } \\
\text { sumed } \\
\text { (average } \\
\text { per day) }\end{array}$ & $\begin{array}{c}\text { Total } N \\
\text { voided } \\
\text { (average } \\
\text { per day) }\end{array}$ & $\begin{array}{c}\text { Mean } \\
\text { daily } \\
\text { nitrogen- } \\
\text { balance }\end{array}$ & $\begin{array}{c}\text { Change } \\
\text { in } \\
\text { weight } \\
\text { for } \\
\text { period } \dagger\end{array}$ & $\begin{array}{l}\text { N con- } \\
\text { sumed } \\
\text { (average } \\
\text { per day) }\end{array}$ & $\begin{array}{c}\text { Total N } \\
\text { voided } \\
\text { (average } \\
\text { per day) }\end{array}$ & $\begin{array}{c}\text { Mean } \\
\text { daily } \\
\text { nitrogen- } \\
\text { balance }\end{array}$ & $\begin{array}{c}\text { Change } \\
\text { in } \\
\text { weight } \\
\text { for } \\
\text { period }\end{array}$ \\
\hline $\begin{array}{l}366-383 \\
387-407 \\
416-432 \\
436-453 \\
457-474 \\
478-495 \\
499-523 \\
534-558 \$ \\
562-575\end{array}$ & $\begin{array}{c}\text { gm. } \\
143.7 \\
144.6 \\
136.8 \\
138.9 \\
150.2 \\
152.6 \\
149.1 \\
145.2 \\
146.6\end{array}$ & $\begin{array}{l}131.8 \\
129.9 \\
144.1 \\
160.0 \\
154.8 \\
161.6 \\
148.4 \\
141.6\end{array}$ & $\begin{array}{r}\text { gm. } \\
+10.9 \\
+12.8 \\
+6.9 \\
-5.2 \\
-9.8 \\
-2.2 \\
-12.5 \\
-3.2 \\
+\quad 5.0\end{array}$ & $\begin{array}{l}-9 \frac{1}{3} \\
+1 \frac{1}{3} \\
-19 \frac{1}{3} \\
+5 \frac{1}{18} \\
-18 \frac{8}{8} \\
-38 \\
+20\end{array}$ & $\begin{array}{c}\text { gm. } \\
143 \cdot 7 \\
144.6 \\
143.6 \\
145 \cdot 8 \\
157 \cdot 7 \\
160 \cdot 2 \\
156 \cdot 6 \\
145 \cdot 6 \\
149.4\end{array}$ & $\begin{array}{l}144.5 \\
143.8 \\
155.9 \\
155.1 \\
154.7 \\
140.8 \\
131.4\end{array}$ & $\begin{array}{l}\text { gm. } \\
-4.9 \\
-1 \cdot 1 \\
-0.9 \\
+\quad 2.0 \\
+1.8 \\
+5.1 \\
+1.9 \\
+4.8 \\
+18.0\end{array}$ & $\begin{array}{l}\text { lb. } \\
-13 \frac{2}{3} \\
+12 \frac{2}{3} \\
+25 \frac{2}{3} \\
+21 \frac{1}{3} \\
+19 \\
+22 \\
+26 \frac{1}{8} \\
+10 \frac{1}{3} \\
+15 \frac{2}{3}\end{array}$ \\
\hline
\end{tabular}

Cow C

\begin{tabular}{|c|c|c|c|}
\hline $\begin{array}{l}\text { Number of } \\
\text { analytical } \\
\text { days }\end{array}$ & $\begin{array}{c}\text { Total N } \\
\text { consumed }\end{array}$ & $\begin{array}{c}\text { Total N } \\
\text { retained } \\
\text { or lost }\end{array}$ & $\begin{array}{l}\text { Nett change } \\
\text { in live- } \\
\text { weight }\end{array}$ \\
\hline $\begin{array}{l}174 \\
428\end{array}$ & $\begin{array}{c}\text { gm. } \\
25,309 \\
62,925\end{array}$ & $\begin{array}{l}\mathrm{gm} . \\
-50 \\
+816\end{array}$ & $\begin{array}{l}1 \mathrm{lb} . \\
-18 \frac{1}{3} \\
+911\end{array}$ \\
\hline
\end{tabular}

Cow D

\begin{tabular}{|c|c|c|}
\hline \multicolumn{3}{|c|}{ Cow D } \\
\hline $\begin{array}{c}\text { Total N } \\
\text { consumed }\end{array}$ & $\begin{array}{l}\text { Total N } \\
\text { retained } \\
\text { or lost }\end{array}$ & $\begin{array}{l}\text { Nett change } \\
\text { in live- } \\
\text { weight }\end{array}$ \\
\hline$\underset{24,019}{\mathrm{gm} .}$ & $\begin{array}{l}\text { gm. } \\
+386\end{array}$ & $\begin{array}{l}\text { lb. } \\
+139 \frac{1}{3}\end{array}$ \\
\hline
\end{tabular}

* From day 562 started feeding new consignment of hay. This proved poorer in nitrogen and ration for days 562 to 575 was consequently altered, and average consumption as follows:

Cow C: $2 \mathrm{l} \cdot 4 \mathrm{lb}$. hay $+\cdot 43 \mathrm{lb}$. linseed cake ( $=8750 \mathrm{gm}$. dry matter per day).

Cow $D: 21.8 \mathrm{lb}$. hay $+.43 \mathrm{lb}$. linseed cake $(=8920 \mathrm{gm}$. dry matter per day).

$\dagger$ Weight of Cow $\mathrm{C}$ at beginning of period, $1378 \mathrm{lb}$.

$\ddagger$ Weight of Cow $D$ at beginning of period, $1407 \mathrm{lb}$.

$\S$ The records for Cow $\mathrm{D}$ in this period relate only to days 534-544. This cow was withdrawn from trial between days 544 and 558 on account of slightly swollen hocks.

|f Does not include weight changes from August 29 to October 31, 1919, during which period no determinations of nitrogen-balance were made.

two cows intersect shortly after service of Cow D; previous to this, the curves run approximately parallel. Thus, on a diet more than sufficient for its protein requirements in the ante-pregnant period, Cow $D$, as a

Journ. of Agric. Sci. XII 


\section{A Study of Nitrogen Metabolism in the Dairy Cow}

result of changes in the early stages of pregnancy, was suffering a loss of protein.

This behaviour is in accord with the findings in other investigations carried out on different species. Murlin ${ }^{1}$ investigated the weekly nitrogenbalances in a pregnant bitch and showed that there was a large loss of maternal protein, commencing immediately after conception and continuing for six weeks. Only during the last two weeks before parturition was there a marked conservation of protein, as manifested in the pronounced nitrogen-retention. Murlin attributed the destruction of maternal protoplasm which accompanies the development of the foetus to the necessity for providing "hereditary building stones for the laying down of the youthful protoplasm in accordance with the type characteristic of the species."

The diet of Cow D was increased by $1 \mathrm{lb}$. seeds hay per day on day 408 and later again on day 562 (see Table IV). This slight increase enabled the cow to begin to retain nitrogen. Reference to Tables IV and $\mathrm{V}$ shows that the rate of storage, however, was not very considerable until within three or four weeks of parturition. During this time, although the amount of nitrogen excreted in the faeces remained roughly at its former level, yet the nitrogen appearing in the urine underwent a marked diminution. This was a consequence of protein-retention. Examining the period as a whole, it would appear that the demands made on the food protein for the single purpose of foetal development were relatively small, since the average rate of nitrogen-retention was only about $2 \cdot 4 \mathrm{gm}$. per day.

The behaviour of Cow C, dry and not in calf, during this period contrasted curiously with its behaviour in the preceding period, when it was able to make a distinct gain of protein and body-weight. In this period, though receiving approximately the same ration, Cow $\mathrm{C}$ suffered a slight loss of protein and its weight dropped about $18 \mathrm{lb}$. These results serve to illustrate further the uncertainty of short period work with animals.

Comments on Table V (Third Main Period of the Experiment).

In Table $\mathrm{V}$ are given the full experimental details for the period immediately preceding and following the calving of Cow D. Particulars of milk-yield, etc., for this and the following period will be found in Table VIII. For some days after parturition, each day's collections of urine, faeces and milk from Cow D were analysed separately.

1 American Journal of Physiology, 1910, xxvII. 177. 
Table V. Nitrogen-balances for Cow $D$ in period of parturition.

Daily ration: $21.5 \mathrm{lb}$. of seeds hay + linseed cake (for amounts on different days see Table).

\begin{tabular}{|c|c|c|c|c|c|c|c|c|}
\hline \multirow[b]{2}{*}{$\begin{array}{l}\text { Days of } \\
\text { period }\end{array}$} & \multicolumn{3}{|c|}{ Consumed } & \multicolumn{4}{|c|}{ Nitrogen voided } & \multirow{2}{*}{$\begin{array}{c}\text { Daily } \\
\text { nitrogen } \\
\text { balance }\end{array}$} \\
\hline & $\begin{array}{l}\text { Lb. of } \\
\text { cake }\end{array}$ & $\begin{array}{l}\text { Total dry } \\
\text { matter }\end{array}$ & Total N & $\begin{array}{l}\text { In } \\
\text { faeces } \\
\text { gm. } \\
76 \cdot 1\end{array}$ & \multirow{2}{*}{$\begin{array}{c}\text { In } \\
\text { urine } \\
\text { gm. } \\
50 \cdot 3 \\
158 \cdot 6 \dagger \\
40 \cdot 4\end{array}$} & \multirow{2}{*}{$\left.\begin{array}{c}\begin{array}{c}\text { In } \\
\text { milk }\end{array} \\
\text { gm. } \\
\overline{51} \cdot 1 \\
87.7\end{array}\right\}$} & $\begin{array}{c}\text { Total } \\
\text { gm. } \\
126 \cdot 4\end{array}$ & \\
\hline $\begin{array}{r}580-586 \\
587 \\
588\end{array}$ & $\begin{array}{l}1 * \\
1 \\
1\end{array}$ & $\begin{array}{l}\text { gm. } \\
9,104 \\
9,174 \\
8,973\end{array}$ & $\begin{array}{l}\text { gm. } \\
141.8 \\
142.5 \\
140.0\end{array}$ & $\begin{array}{c}\text { gm. } \\
76 \cdot 1 \\
-\overline{43 \cdot 7} \\
(2 \text { days })\end{array}$ & & & $\begin{array}{c}\mathrm{gm} . \\
126 \cdot 4 \\
481 \cdot 5\end{array}$ & $\begin{array}{l}\text { gm. } \\
+\quad 15.4 \\
\{-99.5 \\
-99.5\end{array}$ \\
\hline $\begin{array}{r}589 \\
590 \\
591 \\
592 \\
593 \\
594 \\
595 \\
596 \\
597 \\
598-603\end{array}$ & $\begin{array}{l}1 \\
8 \\
8 \\
6 \\
6 \\
6 \\
8 \\
8 \\
8 \\
8\end{array}$ & $\begin{array}{r}9,033 \\
11,826 \\
11,832 \\
10,960 \\
11,024 \\
11,010 \\
11,718 \\
11,730 \\
11,830 \\
11,715\end{array}$ & $\begin{array}{l}140 \cdot 8 \\
280 \cdot 3 \\
280 \cdot 4 \\
239 \cdot 5 \\
240 \cdot 4 \\
248 \cdot 1 \\
286 \cdot 4 \\
286 \cdot 6 \\
288 \cdot 1 \\
286 \cdot 5\end{array}$ & $\begin{array}{r}90 \cdot 0 \\
98 \cdot 9 \\
94 \cdot 6 \\
114 \cdot 5 \\
129 \cdot 3 \\
91 \cdot 4 \\
100 \cdot 8 \\
101 \cdot 9 \\
103 \cdot 4 \\
111 \cdot 6\end{array}$ & $\begin{array}{r}61 \cdot 1 \\
88 \cdot 2 \\
88 \cdot 8 \\
111 \cdot 1 \\
99.3 \\
125.5 \\
108 \cdot 2 \\
102 \cdot 1 \\
108 \cdot 0 \\
111 \cdot 2\end{array}$ & $\begin{array}{r}100 \cdot 0 \\
105 \cdot 7 \\
76 \cdot 2 \\
79 \cdot 5 \\
81 \cdot 7 \\
78 \cdot 2 \\
78 \cdot 4 \\
76 \cdot 5 \\
74 \cdot 8 \\
69 \cdot 2\end{array}$ & $\begin{array}{l}251 \cdot 1 \\
292 \cdot 8 \\
259 \cdot 6 \\
305 \cdot 1 \\
310 \cdot 3 \\
295 \cdot 1 \\
287 \cdot 4 \\
280 \cdot 5 \\
286 \cdot 2 \\
292 \cdot 0\end{array}$ & $\begin{array}{l}-110.3 \\
-\quad 12.5 \\
+\quad 20.8 \\
-65.6 \\
-69.9 \\
-\quad 47.0 \\
-\quad 1.0 \\
+\quad 6.1 \\
+\quad 1.9 \\
-\quad 5.5\end{array}$ \\
\hline \multicolumn{3}{|c|}{ Average from parturition } & 252.5 & $102 \cdot 2$ & 103.5 & $76 \cdot 8$ & $282 \cdot 5$ & $-30 \cdot 0$ \\
\hline
\end{tabular}

* $1 \mathrm{lb}$. linseed cake contained $399.0 \mathrm{gm}$. dry matter and $19.93 \mathrm{gm} . \mathrm{N}$.

$\dagger$ This figure gives $\mathrm{N}$ of urine + fluids + washings. Loss in weight of Cow $\mathrm{D}$ during this period was $161 \mathrm{lb}$.

Cow D calved on the morning of June 17th, 1919 (day 587), the period of gestation being 284 days. The weight of the calf was $84 \mathrm{lb}$. Estimating the protein-content of the calf at 16 per cent. ${ }^{1}$, its nitrogencontent would be $975 \mathrm{gm}$. The placental fluid, urine and washings were collected together and analysed. The placenta weighed $11.5 \mathrm{lb}$. and had a nitrogen-content of $74.6 \mathrm{gm}$. ( $=1.43$ per cent. $N$ in placenta).

Taking the figure $2.4 \mathrm{gm}$. as representing the rate of storage of nitrogen per day during the period of pregnancy, it follows that the total storage of nitrogen by Cow $\mathrm{D}$ during the period of gestation was approximately:

\begin{tabular}{|c|c|c|}
\hline $\begin{array}{l}\text { Up to day } 579 \\
\text { From day } 580\end{array}$ & $\begin{array}{l}\ldots \\
\text { parturition }\end{array}$ & $\begin{array}{l}665 \mathrm{gm} . \\
108\end{array}$ \\
\hline & Thto & 773 \\
\hline
\end{tabular}

The losses of nitrogen during parturition were approximately:

$$
\begin{array}{lllrr}
\text { In calf } & \ldots & \ldots & \ldots & 975 \mathrm{gm} . \\
\text { In placenta, etc. } & \ldots & \ldots & 75,, \\
\cline { 3 - 4 } & & & \text { Total } & 1050,
\end{array}
$$

1 Vide Armsby, The Nutrition of Farm Animals, p. 62. 


\section{A Study of Nitrogen Metabolism in the Dairy Cow}

This figure represents a minimum estimate, since it does not include the nitrogen of the fluids, which were collected with the urine and not analysed separately. Thus, whereas $1050 \mathrm{gm}$. nitrogen had been stored as tissue in the form of calf and placenta, Cow D had been able, on a ration only very slightly heavier than that which served for its protein requirements when not in calf, to obtain $773 \mathrm{gm}$. from its food for this purpose. The deficit of $277 \mathrm{gm}$. must have been supplied from the maternal protein at the average rate of about $1 \mathrm{gm}$. per day.

$A$ cow in calf is thus able to maintain a positive nitrogen-balance on a ration differing only slightly from that requisite for nitrogenous equilibrium in the ante-pregnant period, though under such circumstances, it may have to supply from its own protein a fraction of the nitrogen necessary for foetal growth, and thus be unable to build up the desirable reserves during pregnancy to enable it to come into lactation with a good milk flow capable of being sustained over a long period. More generous feeding than was given in this investigation is obviously necessary in actual farm practice, especially in view of the heavy negative nitrogen-balances shown by Cow $\mathrm{D}$ in the days following parturition.

For the first three days after calving it was thought inadvisable to increase the ration, but on the fourth day (day 590) the allowance of linseed cake was raised to $8 \mathrm{lb}$. This immediately checked the loss of nitrogen from the body, but as the cow at this stage could barely consume the ration, the allowance of linseed cake was reduced two days later (day 592) to $6 \mathrm{lb}$., whereupon a marked nitrogen deficit was again established. On day 595 the allowance of linseed cake was again raised to $8 \mathrm{Ib}$. and nitrogen-equilibrium was practically restored, this changing to nitrogen-retention when on day 608 a further $1 \mathrm{lb}$. of cake was given (vide Table VI).

For the period covered by Table V Cow C, dry and not in calf, was again in nitrogen deficit (see below) following a short period of nitrogen storage from day 562 to 575 .

\begin{tabular}{|c|c|c|c|c|}
\hline Daily ration (days 580-603) & $\begin{array}{c}N \text { consumed } \\
\text { (average } \\
\text { per day) }\end{array}$ & $\begin{array}{l}\text { N voided } \\
\text { (average } \\
\text { per day) }\end{array}$ & $\begin{array}{l}\text { Mean daily } \\
\text { nitrogen-- } \\
\text { balance }\end{array}$ & $\begin{array}{c}\text { Change in } \\
\text { weight for } \\
\text { period }\end{array}$ \\
\hline 21.5 lb. hay $+1 \mathrm{lb}$. linseed cake & $\underset{143.8}{\mathrm{gm} .}$ & $\underset{155.6}{\mathrm{gm}}$ & $\frac{\mathrm{gm}}{-11 \cdot 8}$ & $\begin{array}{l}\text { lb. } \\
+2 \frac{1}{8}\end{array}$ \\
\hline
\end{tabular}

Comments on Table VI (Fourth Main Period of Experiment).

It will be noted from Tables $V$ and VI that a positive nitrogenbalance was not established in Cow D until three weeks after parturition. It was then consuming daily about $330 \mathrm{gm}$. nitrogen and was yielding about $27 \mathrm{lb}$. of milk, containing roughly $60 \mathrm{gm}$. N per day. That the 
ration was then ample for the extra requirements of milk production was evidenced by the consistent positive nitrogen-balances recorded. Towards the end of the trial, when the daily yield of milk had fallen below $20 \mathrm{lb}$. (containing about $48 \mathrm{gm}$. N) the amount of cake fed daily was reduced to $5 \mathrm{lb}$. This resulted in the establishment of a decided negative nitrogen-balance.

\section{Table VI.}

Summary of nitrogen-balances for Cow $D$ during period of lactation.

Daily ration: $21.5 \mathrm{lb}$. seeds hay + linseed cake* (for amounts see Table).

\begin{tabular}{|c|c|c|c|c|c|c|c|c|c|}
\hline \multirow{2}{*}{$\begin{array}{l}\text { Days } \\
\text { of } \\
\text { period }\end{array}$} & \multicolumn{3}{|c|}{$\begin{array}{c}\text { Consumed } \\
\text { (average per day) }\end{array}$} & \multicolumn{4}{|c|}{$\begin{array}{c}\mathrm{N} \text { voided } \\
\text { (average per day) }\end{array}$} & \multirow{2}{*}{$\begin{array}{c}\text { Mean } \\
\text { daily } \\
\text { nitrogen- } \\
\text { balance }\end{array}$} & \multirow{2}{*}{$\begin{array}{l}\text { Change } \\
\text { in } \\
\text { weight } \\
\text { period }\end{array}$} \\
\hline & $\begin{array}{l}\text { Lb. of } \\
\text { cake }\end{array}$ & $\begin{array}{c}\text { Total dry } \\
\text { matter }\end{array}$ & $\underset{\mathrm{N}}{\text { Total }}$ & $\underset{\text { faeces }}{\text { In }}$ & & & Total & & \\
\hline $\begin{array}{l}9-645 \\
60-659 \\
5-680 \\
50-701 \\
6-722\end{array}$ & $\begin{array}{c}9 \\
9 \\
10 \\
9 \dagger \\
7 \\
5\end{array}$ & $\begin{array}{l}12,013 \\
12,039 \\
12,440 \\
11,952 \\
11,153 \\
10,370\end{array}$ & $\begin{array}{c}\mathrm{gm} . \\
329 \cdot 9 \\
349 \cdot 9 \\
340 \cdot 5 \\
323 \cdot 5 \\
287 \cdot 7 \\
241 \cdot 3\end{array}$ & $\begin{array}{r}112.8 \\
111.9 \\
106 \cdot 2 \\
97.4\end{array}$ & $\begin{array}{c}\text { gm. } \\
153.8 \\
169.2 \\
161.4 \\
143.4 \\
124.6 \\
106.5\end{array}$ & $\begin{array}{l}57 \cdot 4 \\
53 \cdot 6 \\
54 \cdot 7 \\
48 \cdot 7\end{array}$ & $\begin{array}{l}\text { gm. } \\
320 \cdot 9 \\
337.2 \\
331 \cdot 6 \\
308 \cdot 9 \\
285 \cdot 5 \\
252 \cdot 6\end{array}$ & $\begin{array}{r}\text { gm. } \\
+9 \cdot 0 \\
+12 \cdot 7 \\
+8 \cdot 9 \\
+14 \cdot 6 \\
+2 \cdot 2 \\
-11 \cdot 3\end{array}$ & $\begin{array}{l}+158 \\
+18 \\
-338 \\
+5 \\
-2 \frac{8}{3}\end{array}$ \\
\hline
\end{tabular}

Condensed Summary for Cow $D$.

Analytical days Total $\mathrm{N}$ consumed Total $\mathrm{N}$ retained

Nett change in weight

$\begin{array}{cccc} & \mathrm{gm} . & \mathrm{gm} . & \mathrm{lb} . \\ 608-624 & 29,131 & +536 \cdot 8 & -18 \\ \mathbf{5 4 6} & +96,051 & +2091 & +78\} \\ 546 & 96,051 & +1041 \S & -\end{array}$

* 1 lb. cake contained $400 \mathrm{gm}$. dry matter and $21 \mathrm{gm}$. nitrogen (approx. average for whole lactation period).

$\dagger$ Amount of cake reduced to $9 \mathrm{lb}$. on day 668 .

$\ddagger$ See note (II) Table IV.

$\S$ Including $N$ of calf and placenta (estimated at minimum of $1050 \mathrm{gm}$.).

During this period of about 90 analytical days in the lactation period, Cow D actually retained about $537 \mathrm{gm}$. of nitrogen and only lost $18 \mathrm{lb}$. body-weight. For the whole trial of $54 \dot{6}$ experimental days, it will be seen that this cow consumed about $96,000 \mathrm{gm}$. nitrogen and of this retained $1040 \mathrm{gm}$. (i.e. slightly over 1 per cent.), this being roughly the amount of nitrogen absorbed in foetal development and lost from the body at parturition.

It was originally intended to continue the experiment through the whole period of lactation, but circumstances rendered this impracticable.

It is of interest to compare in the case of Cow D for the period subsequent to calving (Tables V, VI) the consumption of nitrogen over and above "equilibrium requirements" with the amount of nitrogen secreted in the milk. For this purpose we may take the "equilibrium require- 


\section{A Study of Nitrogen Metabolism in the Dairy Cow}

ment," judged by the previous records of the cows, at roundly $145 \mathrm{gm}$. per day.

\begin{tabular}{|c|c|c|c|c|}
\hline $\begin{array}{c}\text { Day } \\
\text { number }\end{array}$ & $\begin{array}{c}\text { Surplus } N \\
\text { consumed (total } \\
\mathrm{N}-145 \text { gm.) } \\
\text { (average } \\
\text { per day*) }\end{array}$ & $\begin{array}{l}N \text { in milk } \\
\text { (average } \\
\text { per day*) }\end{array}$ & $\begin{array}{l}\text { Ratio of } \\
\text { surplus } N \\
\text { to milk N }\end{array}$ & $\begin{array}{c}\text { Nitrogen- } \\
\text { balance } \\
\text { (average } \\
\text { per day) }\end{array}$ \\
\hline $\begin{array}{l}590-591 \\
592-594 \\
595-603 \\
608-645 \\
650-659 \\
665-680 \\
685-701 \\
706-722\end{array}$ & $\begin{array}{r}\text { gm. } \\
135 \\
98 \\
142 \\
195 \\
195 \\
178 \\
143 \\
96\end{array}$ & $\begin{array}{c}\text { gm. } \\
91 \\
80 \\
72 \\
59 \\
57 \\
54 \\
55 \\
49\end{array}$ & $\begin{array}{l}1 \cdot 5: 1 \\
1 \cdot 2: 1 \\
2 \cdot 0: 1 \\
3 \cdot 3: 1 \\
3 \cdot 4: 1 \\
3 \cdot 3: 1 \\
2 \cdot 6: 1 \\
2 \cdot 0: 1\end{array}$ & $\begin{array}{r}\text { gm. } \\
+\quad 4.1 \\
-60.9 \\
-\quad 2.9 \\
+10.8 \\
+\quad 8.9 \\
+14.6 \\
+2.2 \\
-11.3\end{array}$ \\
\hline
\end{tabular}

It is clearly evident why during days 592-594 a heavy nitrogen deficit was recorded, since the "surplus" nitrogen, even without allowance for digestibility, was barely greater than the nitrogen removed from the body in the milk. Even in the period, days 595-603, when the "surplus" nitrogen was roughly twice that secreted in the milk, equilibrium was barely established, and again later, in the period, days 706-722, when a similar proportion prevailed, nitrogen deficit again set in. In the intervening periods when the proportion was well over $3: 1$ a substantial nitrogen-retention was effected.

It would appear therefore that in order to prevent loss of nitrogen from the body of the lactating cow the "surplus" nitrogen must amount to well over twice the amount of nitrogen secreted in the milk. This is a condition which may well be difficult to satisfy in practice. Cow $\mathrm{D}$ was only a moderate milker (about $28 \mathrm{lb}$. milk daily at maximum), and yet it required the heavy and highly nitrogenous rations indicated to prevent loss of nitrogen from the body. With the more liberal milk-flow so often achieved with the modern dairy cow it would be even more difficult to secure nitrogen-equilibrium, if not indeed beyond the food-consuming capacity of the cow. This is fully in accord with practical experience of the difficulty of maintaining the "condition" of the milch cow in the early stages of lactation.

The full details for Cow $\mathrm{C}$ (dry and not in calf) are not given for this period, as they present no new features of interest. The establishment of a positive nitrogen balance is noteworthy, since on the same ration in the preceding period, a decided negative balance was recorded. An examination of the figures for the complete trial shows, however, that Cow $\mathrm{C}$ had been able to store about $1000 \mathrm{gm}$. of nitrogen from the $81,000 \mathrm{gm}$. consumed. 
Table VII.

Condensed summary for Cow $C$ between the days 608 and 722.

Daily ration: $21.5 \mathrm{lb}$. seeds hay $+1 \mathrm{lb}$. linseed cake.

$\begin{array}{cccc}\begin{array}{c}\text { Analytical } \\ \text { days }\end{array} & \begin{array}{c}\text { Total N } \\ \text { consumed }\end{array} & \begin{array}{c}\text { Total N } \\ \text { retained }\end{array} & \begin{array}{c}\text { Nett change } \\ \text { of weight }\end{array} \\ \mathbf{9 4} & \text { gm. } & \text { gm. } & \text { lb. } \\ \mathbf{5 4 6} & \mathbf{1 4 , 6 3 9} & +\mathbf{4 7 2} & +13 \frac{8}{3} \\ & \mathbf{8 1 , 0 1 5} & +1005 & +107\end{array}$

Table VIII. Milk records of Cow D.

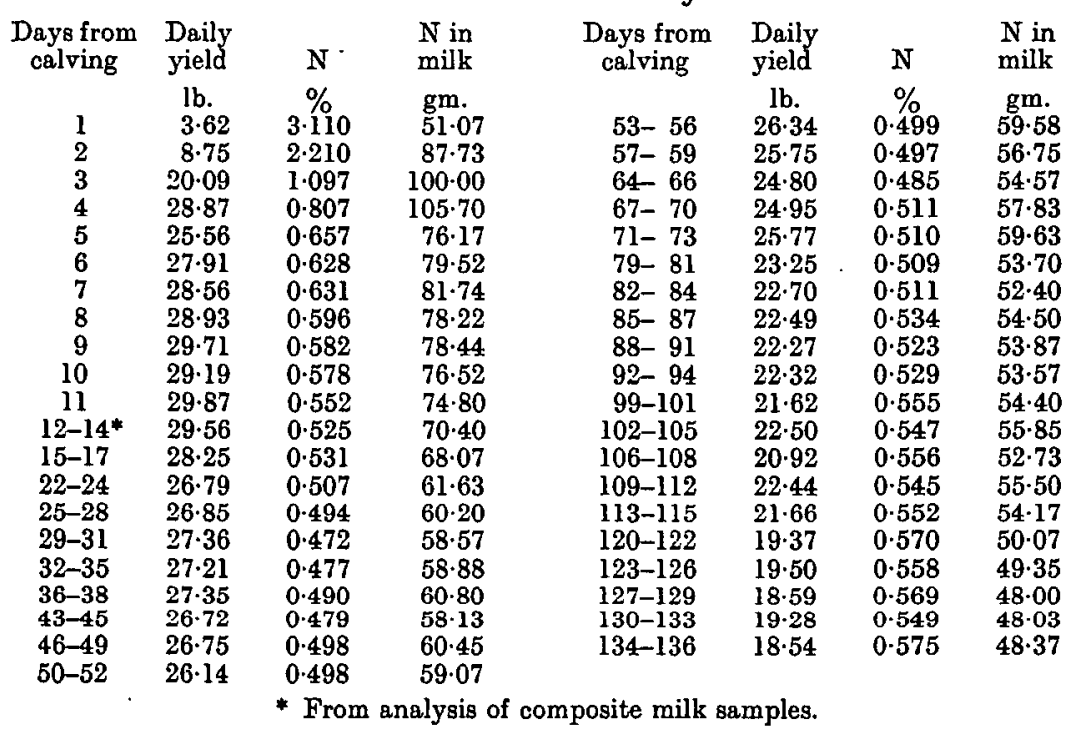

\section{SUMMARY.}

This communication deals with the results of two experiments in which the "nitrogen-balance," or difference between nitrogen-consumption and nitrogen-excretion by the cow, has been studied over prolonged periods, starting with the "dry" cow, not in calf, proceeding through the whole period of pregnancy and well into the period of active lactation.

Experiment 1 was performed throughout with the two cows, "dry" and not in calf, receiving a basal ration of hay to which was added increasing amounts of maize meal with a view to securing a progressively increasing consumption of nitrogen. This experiment lasted 196 days, during which period determinations of the nitrogen-balance were made on 90 days.

Experiment 2 was carried out similarly with two cows, and covered a period of 722 days, including 546 days on which determinations of the nitrogen-balance were made. Throughout the whole of this period one 


\section{A Study of Nitrogen Metabolism in the Dairy Cow}

cow (Cow C) was maintained "dry" and not in calf, as control cow, whilst the other cow (Cow D) after 302 days became pregnant and its record was followed throughout the stages of pregnancy and parturition and for the first 136 days of active lactation.

The outstanding features of the results are as follows:

(1) With the progressive increase of nitrogen-consumption beyond the fundamental requirements of the dry cow the rate of nitrogen-retention steadily increases to a maximum and then falls. The maximum appears to be attained under the conditions of our experiment with a protein-supply in the neighbourhood of $2 \cdot 4 \mathrm{~kg}$. crude protein per $1000 \mathrm{~kg}$. live-weight. There are indications that this figure may be independent of the nature of the foods fed along with hay.

(2) When the cow is maintained upon a ration which causes an initial nitrogen-retention the rate of retention falls steadily, but a very prolonged period-up to 90-100 days-may be necessary before nitrogenequilibrium is attained.

(3) Even after nitrogen-equilibrium is established and a relatively constant nitrogen-consumption is maintained, there may arise from time to time considerable deviations from equilibrium either in the positive or negative direction. It would appear therefore that for reliable work of this character long experimental periods are essential.

(4) The very earliest stages of pregnancy are marked by a profound disturbance of nitrogen metabolism, the requirement for maintenance of nitrogen-equilibrium being very sensibly increased. This additional requirement persists at a steadily reduced rate for some 15 to 20 weeks, after which it is very small. Over the whole period of pregnancy the average rate of nitrogen-retention was only about $2.4 \mathrm{gm}$. per day.

(5) During parturition and for a few days subsequently the output of nitrogen is very great and more than can be restored rapidly by foodconsumption. With the experimental cow, giving barely three gallons of milk per day at most, some two to three weeks elapsed after calving before nitrogen-equilibrium was restored.

(6) It would appear that to maintain nitrogen-equilibrium during lactation, the food must supply from twice to three times the amount of nitrogen secreted in the milk, in addition to that required for the maintenance of equilibrium in the "dry" state. This represents a foodconsumption which would be difficult to attain in the case of cows giving large yields of milk, and accounts for the familiar difficulty of maintaining the "condition" of such cows in the earlier stages of lactation. 